\title{
Number of replicates and experimental precision statistics in corn
}

\author{
Alberto Cargnelutti Filho(1), Marcos Toebe ${ }^{(2)}$, Bruna Mendonça Alves(1), \\ Jéssica Andiara Kleinpaul(1) and Ismael Mario Marcio Neu ${ }^{(1)}$
}

\begin{abstract}
(1)Universidade Federal de Santa Maria, Departamento de Fitotecnia, Avenida Roraima, no 1.000, Camobi, CEP 97105-900 Santa Maria, RS, Brazil. E-mail: alberto.cargnelutti.filho@gmail.com, brunamalves11@gmail.com, kleinpauljessica@gmail.com, ismaelmmneu@hotmail.com (2)Universidade Federal de Santa Maria, Departamento de Ciências Agronômicas e Ambientais, Campus Frederico Westphalen, Linha 7 de Setembro, s/nº, BR 386, Km 40, CEP 98400-000 Frederico Westphalen, RS, Brazil. E-mail: m.toebe@gmail.com
\end{abstract}

\begin{abstract}
The objective of this work was to evaluate the influence of the number of replicates on experimental precision in corn (Zea mays). Data on the grain yield of 15 corn cultivars, evaluated in a randomized complete block design, with nine replicates $(r=9)$, were used. From the experiment with nine replicates, further experiments were conducted with combinations of $2,3, \ldots, \mathrm{r}-1$ replicates. The analysis of variance was carried out for each experiment. Experimental precision statistics and central tendency and variability measures were calculated, dispersion diagrams were prepared, and models of these statistics were adjusted as a function of the number of replicates. The number of replicates was determined by the visual analysis of the graphs with the experimental precision statistics. Increasing the number of replicates improves the estimates of experimental precision but decreases gains. Therefore, the increase in the number of replicates is important to improve corn cultivar discrimination. Six replicates are recommended as the benchmark for experiments with corn cultivars. Fasoulas' differentiation index, based on the percentage of significant contrasts, is an appropriate statistic for evaluating experimental precision.
\end{abstract}

Index terms: Zea mays, cultivar discrimination, Fasoulas' index, least significant difference.

\section{Número de repetições e estatísticas de precisão experimental em milho}

Resumo-O objetivo deste trabalho foi avaliar a interferência do número de repetições na precisão experimental, em milho (Zea mays). Foram utilizados dados de produtividade de grãos de 15 cultivares de milho, avaliada em blocos ao acaso, com nove repetições $(\mathrm{r}=9)$. A partir do experimento com nove repetições, formaram-se experimentos pelas combinações de $2,3, \ldots, r-1$ repetições. Para cada experimento, foi realizada a análise de variância. Foram calculadas estatísticas de precisão experimental e medidas de tendência central e de variabilidade, confeccionados diagramas de dispersão e ajustados modelos dessas estatísticas em função do número de repetições. O número de repetições foi determinado pela análise visual dos gráficos das estatísticas de precisão experimental. $\mathrm{O}$ aumento do número de repetições melhora a precisão experimental, mas diminui os ganhos. Portanto, o aumento do número de repetições é importante para aumentar a discriminação das cultivares de milho. Recomendam-se seis repetições como referência para experimentos com cultivares de milho. $\mathrm{O}$ índice de diferenciação de Fasoulas, baseado no percentual de contrastes significativos, é uma estatística apropriada para avaliar a precisão experimental.

Termos para indexação: Zea mays, discriminação de cultivares, índice de Fasoulas, diferença mínima significativa.

\section{Introduction}

In plant breeding programs, cultivar comparison experiments are conducted with the aim of selecting the best genotypes and discarding the least promising ones. In this context, it is important that small differences between cultivar means be identified as significant, i.e., not attributed to chance.

High-precision trials are required to properly discriminate cultivars. Statistics for evaluating experimental precision have already been studied by several authors (Pimentel-Gomes, 1990; Pimentel Gomes, 1991; Lúcio et al., 1999; Cargnelutti Filho \& Storck, 2007, 2009; Resende \& Duarte, 2007; Cargnelutti Filho et al., 2014) and class boundaries have been established.

A statistic commonly used by researchers as a measure of experimental precision is the coefficient of experimental variation (CVe) (Pimentel-Gomes, 1990). For agricultural trials, Pimentel-Gomes 
(1990) established the following CVe classes: low, less than $10 \%$; average, between 10 and $20 \%$; high, between 20 and 30\%; and very high, higher than 30\%. According to Pimentel Gomes (1991), the variation rate (VR), defined as the standard error, expressed as a percentage of the mean, has proved to be an advantageous substitute for CVe in evaluating the number of replicates required. Lúcio et al. (1999) used the least significant difference as a percentage of the mean (LSD\%), based on Tukey's test, to assess experimental precision. These authors established the following limits for LSD\% in corn cultivar trials: very low, $\leq 9.0$; low, $9.0<\mathrm{LSD} \% \leq 25.5$; average, $25.5<$ LSD $\% \leq 48.5$; high, $48.5<\mathrm{LSD} \% \leq 65.0$; and very high, $>65.0$. Experiments with lower estimates of CVe (Pimentel-Gomes, 1990), VR (Pimentel Gomes, 1991), and LSD\% (Lúcio et al., 1999) are desirable, since they would enhance experimental precision and improve the reliability of inferences (Storck et al., 2016).

Studies on the application of experimental precision statistics based on data from corn cultivar trials were conducted by Cargnelutti Filho \& Storck (2007, 2009). Theoretical aspects have also been addressed in Resende \& Duarte (2007), who also established experimental precision classes for cultivar F-test values (F) and selection accuracy (SA). The experimental precision class boundaries established by the latter authors are as follows: very high, $\mathrm{F} \geq 5.2632$ and SA $\geq 0.90$; high, $1.9608 \leq \mathrm{F}<5.2632$ and $0.70 \leq \mathrm{SA}<$ 0.90 ; moderate, $1.3333 \leq \mathrm{F}<1.9608$ and $0.50 \leq \mathrm{SA}<$ 0.70 ; and low, $\mathrm{F}<1.3333$ and $\mathrm{SA}<0.50$. Experiments with higher F-test and SA scores are more precise. The advantages of this approach have been acknowledged in different works (Cargnelutti Filho \& Storck, 2007, 2009; Resende \& Duarte, 2007).

Another experimental precision statistic studied by Cargnelutti Filho \& Storck $(2007,2009)$ is Fasoulas' differentiation index (FI) (Fasoulas, 1983). It indicates the percentage of statistical differences among cultivar means that can be detected by the multiple means comparison method. FI ranges from $0 \%$ (no significant mean contrasts) to $100 \%$ (contrasts for all significant means) and has been considered adequate for classifying experimental precision (Cargnelutti Filho \& Storck, 2007). Higher FI scores are desirable and indicate greater experimental precision, i.e., allow a more accurate cultivar discrimination.
The number of replicates is an important factor in experimental protocols. Replicates are necessary to estimate experimental error and provide the conditions required to test the hypothesis or hypotheses formulated. The quality of the estimated mean is directly proportional to the number of replicates, since the standard error for the mean is calculated by $s / \sqrt{ }$, where $\mathrm{s}$ is the experimental standard error deviation and $\mathrm{r}$ is the number of replicates (Ramalho et al., 2012; Banzatto \& Kronka, 2013; Storck et al., 2016). Using an appropriate number of replicates to provide a good estimate of experimental error increases the accuracy of estimated means and also boosts the power of statistical tests. Studies linking the number of replicates to experimental precision have been conducted in corn (Velini et al., 2006; Cargnelutti Filho et al., 2010; Nesi et al., 2010; Curti et al., 2014; Gordón-Mendoza \& Camargo-Buitrago, 2015), showing promising results with an increasing number of replicates.

However, few studies have been carried out specifically considering the possibility of improving experimental precision by increasing the number of replicates, even in very high-precision experiments. An insufficient number of replicates can produce inaccurate estimates, whereas arbitrarily increasing this number can result in wasted time, labor and financial resources, since gains may become inexpressive. According to the criteria proposed by Resende \& Duarte (2007), it is assumed that cultivar discrimination can be increased by increasing the number of replicates, even in very high-precision experiments $(\mathrm{F} \geq 5.2632$; $\mathrm{SA} \geq 0.90)$. Therefore, a statistic that provides the number of significant contrasts by applying a means comparison test, in this case FI, could be appropriate as a measurement of experimental precision. It is important to determine the number of replicates to increase significant contrasts, without making gains insignificant.

The objective of this work was to evaluate the influence of the number of replicates on experimental precision in corn.

\section{Materials and Methods}

The experiment was conducted in the 2012/2013 crop year, with 15 corn (Zea mays L.) cultivars, at the Department of Plant Science of Universidade Federal de Santa Maria, located in the municipality of Santa 
Maria, in the state of Rio Grande do Sul, Brazil $\left(29^{\circ} 42^{\prime} \mathrm{S}, 53^{\circ} 49^{\prime} \mathrm{W}\right.$, at $95 \mathrm{~m}$ altitude). A randomized complete block design, with nine replicates, was used. The experimental units consisted of two $5.0-\mathrm{m}$ rows, $0.8 \mathrm{~m}$ apart for a density of 62,500 plants per hectare. At harvesting, grain yield was determined for each experimental unit, corrected for $13 \%$ moisture content.

From the experiment with 9 replicates $(r=9)$, further experiments were carried out with combinations of 2 , $3, \ldots, r-1$ replicates. Therefore, the initial experiment was considered as a reference $\left[\mathrm{C}_{(9.9)}=1\right.$ experiment] for the others, in which the 9 replicates were combined into groups of $2\left[\mathrm{C}_{(9.2)}=36\right], 3\left[\mathrm{C}_{(9.3)}=84\right], 4$ $\left[\mathrm{C}_{(9.4)}=126\right], 5\left[\mathrm{C}_{(9.5)}=126\right], 6\left[\mathrm{C}_{(9.6)}=84\right], 7\left[\mathrm{C}_{(9.7)}=36\right]$, and $8\left[\mathrm{C}_{(9.8)}=9\right]$ replicates, totaling 502 experiments.

The analysis of variance was carried out in each experiment, based on the mathematical model $Y_{i j}=\mu+C_{i}+B_{j}+\varepsilon_{i j}$, where $Y_{i j}$ is the observed value for variable $Y$ of the $i^{\text {th }}$ cultivar $(i=1,2, \ldots, n)$ in the $\mathrm{j}^{\text {th }}$ replicate (block) $(\mathrm{j}=1,2, \ldots, \mathrm{r}) ; \mu$ is the overall mean; $C_{i}$ is the effect of the $i^{\text {th }}$ cultivar $(i=1,2, \ldots, n)$, considered herein as a random effect; $B_{j}$ is the effect of the $\mathrm{j}^{\text {th }}$ replicate (block) $(\mathrm{j}=1,2, \ldots, \mathrm{r})$; and $\varepsilon_{\mathrm{ij}}$ is the effect of the experimental error for $Y_{\mathrm{ij}}$, assumed to be normal and independently distributed with a zero mean and common variance $\left(\sigma^{2}\right)$ (Storck et al., 2016).

From the results of the analysis of variance for each experiment, the block mean square (BMS), cultivar mean square (CMS), error mean square (EMS), cultivar F-test value ( $\mathrm{F}=\mathrm{CMS} / \mathrm{EMS})$, and overall experimental mean (m) were obtained. The mean phenotypic variance $(\mathrm{Vfen}=\mathrm{CMS} / \mathrm{r})$, genotypic variance $($ Vgen $=(C M S-E M S) / r)$, and mean residual variance $($ Vres $=\mathrm{EMS} / \mathrm{r}$ ) were also estimated as in Cruz et al. (2012). Then, the coefficients of experimental variation $(\mathrm{CVe})$ and genetic variation $(\mathrm{CVg})$ were calculated as percentages, using the following expressions: $\mathrm{CVe}=100 \sqrt{\mathrm{EMS}} / \mathrm{m} \quad$ and $\quad \mathrm{CVg}=100 \sqrt{\mathrm{Vgen}} / \mathrm{m}$ (Cruz et al., 2012). The percentage variation rate (VR) was estimated by: $\mathrm{VR}=100 \sqrt{\mathrm{EMS} / \mathrm{r}} / \mathrm{m}$ (Pimentel Gomes, 1991) or $\mathrm{VR}=(100 \sqrt{\mathrm{EMS}} / \mathrm{m}) / \sqrt{\mathrm{r}}$; therefore, $\mathrm{VR}=\mathrm{CVe} / \sqrt{\mathrm{r}}$, where $\mathrm{r}$ is the number of replicates.

The least significant difference (LSD) between cultivars by Tukey's test, at 5\% probability, was obtained using the expression: $L S D=q_{\alpha\left(n_{i} \text { Edf }\right)} \sqrt{E M S / r}$, where $\mathrm{q}_{\alpha(\mathrm{n} ; \mathrm{Edf})}$ is the critical value for Tukey's test; $\mathrm{n}$ is the number of cultivars $(n=15)$; Edf is the error degrees of freedom, i.e., $\mathrm{Edf}=(\mathrm{r}-1)(\mathrm{n}-1)$; EMS is the error mean square; and $\mathrm{r}$ is the number of replicates. The LSD between cultivars by Tukey's test, expressed as a percentage of the mean for the experiment (LSD \%), was estimated as $\mathrm{LSD} \%=100 \mathrm{LSD} / \mathrm{m}$. SA was obtained according to Resende \& Duarte (2007) by $\mathrm{SA}=(1-1 / \mathrm{F})^{0.5}$. Tukey's test was applied, at $5 \%$ probability, to compare cultivar means. Then, for each experiment, FI was calculated through the expression $\mathrm{FI}=200 \sum_{\mathrm{i}=1}^{\mathrm{n}} \mathrm{m}_{\mathrm{i}} /[\mathrm{n}(\mathrm{n}-1)]$ (Fasoulas, 1983), where $\mathrm{n}$ is the number of cultivars $(n=15)$ and $m_{i}$ is the number of means exceeded statistically by the $\mathrm{i}^{\text {th }}$ cultivar after Tukey's test. It should be pointed out that FI is the percentage of statistical differences among means that multiple comparison (Tukey's test) can detect.

Therefore, 502 estimates were obtained for BMS, CMS, EMS, F, m, Vfen, Vgen, Vres, CVe, CVg, VR, LSD, LSD $\%$, SA, and FI - 36, 84, 126, 126, 84, 36, 9, and 1, respectively, for the experiments with 2, $3,4,5,6,7,8$, and 9 replicates. For each number of replicates, the minimum, maximum, amplitude (maximum - minimum), and means of BMS, CMS, EMS, F, m, Vfen, Vgen, Vres, CVe, CVg, VR, LSD, LSD $\%$, SA, and FI were calculated. Scatter diagrams were prepared, and models were adjusted in order to visualize the behavior patterns of these statistics as a function of the number of replicates. The number of replicates was determined by the visual examination of the graphs used for stabilization of the mean experimental precision statistics. The statistical analysis was performed using Microsoft Office Excel and the Genes program (Cruz, 2013).

\section{Results and Discussion}

For the experiment with nine replicates, the results of the Shapiro-Wilk ( $\mathrm{SW}=0.987444 ; \mathrm{p}=0.2573$ ) and Bartlett $\left(\chi^{2}=15.4484 ; p=0.3482\right)$ tests revealed that the residual normality and homogeneity of variance assumptions were satisfied, statistically validating the results of the analysis of variance and Tukey's test (Storck et al., 2016). The actual data obtained could, therefore, be used in the statistical analysis of the 502 experiments. The analysis of variance of the 36,84 , $126,126,84,36,9$, and 1 experiments conducted with 2 , $3,4,5,6,7,8$, and 9 replicates, respectively, indicated a significant block effect $(\mathrm{p} \leq 0.05)$ of $66.67,86.90,96.03$, $98.41,100,100,100$, and $100 \%$ of the experiments. The percentage of experiments with a significant

Pesq. agropec. bras., Brasília, v.53, n.11, p.1213-1221, Nov. 2018 DOI: 10.1590/S0100-204X2018001100003 
effect $(p \leq 0.05)$ increased in proportion to the number of replicates. These results show that the use of blocks was efficient for most experiments with 2, 3, 4, and 5 replicates and for $100 \%$ of the experiments with more replicates. Cargnelutti Filho et al. (2010) used 286 trials with three replicates to study corn cultivar grain yield; the F-test run on the analysis of variance revealed a significant block effect $(\mathrm{p} \leq 0.05)$ in 120 trials, i.e., in $41.96 \%$ of them. The authors concluded that in most cases $(58.04 \%)$, due to the insignificance of the block effect, the use of a completely randomized design is appropriate; however, in this kind of experiment, blocks should be treated as a way of ensuring that the source of heterogeneity, if there is any, is controlled.

There was a significant cultivar effect $(p \leq 0.05)$ in the experiment with 9 replicates, treated herein as a benchmark; in the 36 experiments with 2 replicates, i.e., cultivars differed in regard to grain yield even with a reduced number of replicates; and in all other experiments, with $3,4,5,6,7$, and 8 replicates. Therefore, in the 502 planned experiments, the comparison of means by Tukey's test was an appropriate procedure for discriminating cultivars.

The minimum values of BMS and EMS increased when 2 to 9 replicates were added. However, maximum values and, consequently, amplitude (maximum minimum) decreased, showing the improved precision of BMS and EMS estimates as the number of replicates was increased (Table 1 and Figure 1). Since the means of BMS (13.137) and EMS (0.814) remained constant as the number of replicates increased, there is no effect of number of replicates, although the precision of estimates is improved. The lack of alterations in the mean as the number of replicates increased was expected and is in alignment with the mathematical model of the randomized complete block design with random cultivar effect, in which the expected EMS is $\sigma^{2}$ and the expected BMS is $\sigma^{2}+n \sigma_{b}^{2}$ (Storck et al., 2016). Therefore, for a fixed number of cultivars $(n=15)$, a constant value is expected for EMS and BMS, regardless of the number of replicates.

The relationship between CMS and number of replicates (r), based on the 502 experiments $\left(\mathrm{CMS}=0.8139+2.950 \mathrm{r} ; \mathrm{R}^{2}=0.9044\right)$ and on the experimental mean for each $\mathrm{r}(\mathrm{CMS}=0.8139+2.950 \mathrm{r}$; $\left.\mathrm{R}^{2}=1\right)$, became increasingly linear. The estimates of the intercept (0.8139) and the angular coefficient of linear regression (2.950) correspond, respectively, to
EMS and Vgen. The two databases used - in this case, all experiments and means of the experiments for each $\mathrm{r}$-produce the same linear model parameter estimates, but with different coefficients of determination. This relationship is expected, because the mathematical model of the randomized complete block design with a random cultivar effect implies an expected CMS of $\sigma^{2}+\mathrm{r}_{\mathrm{g}}{ }^{2}$ (Storck et al., 2016), where $\sigma^{2}$ is EMS, $r$ is the number of replicates, and $\sigma_{\mathrm{g}}{ }^{2}$ is Vgen.

The amplitude of $\mathrm{F}$ decreased as $\mathrm{r}$ increased, showing that precision improves as more replicates are performed. Since $F=C M S / E M S$, it can be inferred that $\mathrm{F}=(\mathrm{EMS}+\mathrm{rVgen}) / \mathrm{EMS}$, i.e., $\mathrm{F}=(\mathrm{EMS} / \mathrm{EMS})$ $+(\mathrm{rVgen} / \mathrm{EMS})$ or $\mathrm{F}=1+(\mathrm{rVgen} / \mathrm{EMS})$. Therefore, the relationship between $\mathrm{F}$ and $\mathrm{r}$ shows an increasingly linear pattern, based on the 502 experiments $(\mathrm{F}=$ $\left.1+3.6820 \mathrm{r} ; \mathrm{R}^{2}=0.6960\right)$ and on the mean of the experiments for each $r\left(F=1+3.6543 r ; R^{2}=0.9989\right)$. Considering Vgen (2.950) and EMS (0.8139) remain constant as $\mathrm{r}$ increases, there is a perfect relationship $\left(\mathrm{R}^{2}=1\right)$ between $\mathrm{F}$ and $\mathrm{r}$, expressed as $\mathrm{F}=1+(\mathrm{r} \times$ $2.95001972 / 0.81387726$ ), i.e. $\mathrm{F}=1+3.6246$ r. Therefore, the F-value increases by 3.6246 for each additional replicate. Even though, with 2 replicates, the F-value indicates a high-precision experiment $(F \geq 5.2632)$ (Resende \& Duarte, 2007), these results suggest that it is still possible to improve experimental precision by increasing $r$. However, experimental precision classes based on F would need to be reviewed, as they may not cover these situations.

The minimum values of $\mathrm{m}$ increased in direct proportion to r, rising from 2 to 9 , and the maximum values decreased. Consequently, amplitude decreased, indicating that the precision of the estimated mean improved as $r$ increased, although the mean remained constant at $8.395 \mathrm{Mg} \mathrm{ha}^{-1}$ (Table 1 and Figure 1). These results are in alignment with those of Ramalho et al. (2012), Banzatto \& Kronka (2013), and Storck et al. (2016) regarding improved experimental precision as the number of replicates is increased.

As to mean Vfen and Vgen, minimum values increased and maximum values decreased as $r$ increased, narrowing amplitude and improving the precision of these estimates. The relationship between Vfen and $r$ can be expressed by replacing CMS in the expression $\mathrm{Vfen}=\mathrm{CMS} / \mathrm{r}$, i.e., Vfen $=\mathrm{EMS}+\mathrm{rVgen} / \mathrm{r}$, and, therefore, $\mathrm{Vfen}=\mathrm{EMS} / \mathrm{r}+$ Vgen. The relationship between Vfen and $r$, based on the 502 experiments, 
Table 1. Minimum (Min), maximum (Max), amplitude (Amp), and average of the estimates of block mean square (BMS), cultivar mean square (CMS), error mean square (EMS), cultivar F-test value (F), overall experimental mean (m), mean phenotypic variance (Vfen), mean genotypic variance (Vgen), mean residual variance (Vres), coefficient of experimental variation $(\mathrm{CVe})$, coefficient of genetic variation $(\mathrm{CVg})$, percentage variation rate (VR), least significant difference (LSD), LSD as a percentage of the mean for the experiment (LSD\%), selection accuracy (SA), and Fasoulas' differentiation index (FI) for grain yield $\left(\mathrm{Mg} \mathrm{ha}^{-1}\right)$ of 15 corn (Zea mays) cultivars, obtained in experiments using combinations (c) of 2, 3, ..., 9 replicates (r).

\begin{tabular}{|c|c|c|c|c|c|c|c|c|c|c|c|c|c|}
\hline $\mathrm{r}$ & $\mathrm{c}$ & Min & Max & Amp & Average & Min & Max & Amp & Average & Min & Max & Amp & Average \\
\hline & & \multicolumn{4}{|c|}{ BMS } & \multicolumn{4}{|c|}{ CMS } & \multicolumn{4}{|c|}{ EMS } \\
\hline 2 & 36 & 0.007 & 61.001 & 60.994 & 13.137 & 3.743 & 8.228 & 4.485 & 6.714 & 0.354 & 1.237 & 0.883 & 0.814 \\
\hline 3 & 84 & 0.054 & 34.711 & 34.657 & 13.137 & 6.505 & 11.766 & 5.261 & 9.664 & 0.462 & 1.123 & 0.662 & 0.814 \\
\hline 4 & 126 & 0.557 & 27.123 & 26.566 & 13.137 & 9.407 & 15.398 & 5.991 & 12.614 & 0.512 & 1.066 & 0.554 & 0.814 \\
\hline 5 & 126 & 1.685 & 22.457 & 20.772 & 13.137 & 12.698 & 18.875 & 6.177 & 15.564 & 0.625 & 0.986 & 0.361 & 0.814 \\
\hline 6 & 84 & 3.002 & 19.418 & 16.416 & 13.137 & 16.233 & 21.816 & 5.583 & 18.514 & 0.699 & 0.927 & 0.228 & 0.814 \\
\hline 7 & 36 & 6.215 & 17.270 & 11.055 & 13.137 & 19.838 & 24.663 & 4.825 & 21.464 & 0.737 & 0.892 & 0.155 & 0.814 \\
\hline 8 & 9 & 8.530 & 14.978 & 6.448 & 13.137 & 23.534 & 26.311 & 2.777 & 24.414 & 0.777 & 0.857 & 0.081 & 0.814 \\
\hline \multirow[t]{2}{*}{9} & 1 & 13.137 & 13.137 & 0.000 & 13.137 & 27.364 & 27.364 & 0.000 & 27.364 & 0.814 & 0.814 & 0.000 & 0.814 \\
\hline & & \multicolumn{4}{|c|}{$\mathrm{F}$} & \multicolumn{4}{|c|}{$\mathrm{m}$} & \multicolumn{4}{|c|}{ Vfen } \\
\hline 2 & 36 & 3.582 & 22.823 & 19.240 & 9.181 & 7.106 & 9.353 & 2.247 & 8.395 & 1.872 & 4.114 & 2.243 & 3.357 \\
\hline 3 & 84 & 6.326 & 24.468 & 18.142 & 12.385 & 7.282 & 9.258 & 1.976 & 8.395 & 2.168 & 3.922 & 1.754 & 3.221 \\
\hline 4 & 126 & 10.069 & 28.593 & 18.524 & 15.853 & 7.530 & 9.190 & 1.659 & 8.395 & 2.352 & 3.850 & 1.498 & 3.153 \\
\hline 5 & 126 & 14.116 & 29.204 & 15.088 & 19.380 & 7.760 & 9.087 & 1.327 & 8.395 & 2.540 & 3.775 & 1.235 & 3.113 \\
\hline 6 & 84 & 18.232 & 31.169 & 12.937 & 22.929 & 7.964 & 8.952 & 0.988 & 8.395 & 2.706 & 3.636 & 0.931 & 3.086 \\
\hline 7 & 36 & 22.514 & 33.448 & 10.934 & 26.488 & 8.122 & 8.764 & 0.642 & 8.395 & 2.834 & 3.523 & 0.689 & 3.066 \\
\hline 8 & 9 & 27.822 & 33.492 & 5.670 & 30.053 & 8.244 & 8.600 & 0.356 & 8.395 & 2.942 & 3.289 & 0.347 & 3.052 \\
\hline \multirow[t]{2}{*}{9} & 1 & 33.622 & 33.622 & 0.000 & 33.622 & 8.395 & 8.395 & 0.000 & 8.395 & 3.040 & 3.040 & 0.000 & 3.040 \\
\hline & & \multicolumn{4}{|c|}{ Vgen } & \multicolumn{4}{|c|}{ Vres } & \multicolumn{4}{|c|}{$\mathrm{CVe}$} \\
\hline 2 & 36 & 1.349 & 3.866 & 2.516 & 2.950 & 0.177 & 0.618 & 0.441 & 0.407 & 6.374 & 14.799 & 8.425 & 10.722 \\
\hline 3 & 84 & 1.869 & 3.742 & 1.873 & 2.950 & 0.154 & 0.374 & 0.221 & 0.271 & 7.747 & 13.412 & 5.665 & 10.751 \\
\hline 4 & 126 & 2.130 & 3.669 & 1.540 & 2.950 & 0.128 & 0.266 & 0.138 & 0.203 & 8.476 & 12.765 & 4.289 & 10.753 \\
\hline 5 & 126 & 2.360 & 3.629 & 1.269 & 2.950 & 0.125 & 0.197 & 0.072 & 0.163 & 9.297 & 12.309 & 3.012 & 10.751 \\
\hline 6 & 84 & 2.570 & 3.519 & 0.950 & 2.950 & 0.116 & 0.155 & 0.038 & 0.136 & 9.673 & 11.940 & 2.266 & 10.750 \\
\hline 7 & 36 & 2.714 & 3.418 & 0.704 & 2.950 & 0.105 & 0.127 & 0.022 & 0.116 & 9.997 & 11.623 & 1.626 & 10.748 \\
\hline 8 & 9 & 2.836 & 3.191 & 0.355 & 2.950 & 0.097 & 0.107 & 0.010 & 0.102 & 10.306 & 11.153 & 0.847 & 10.747 \\
\hline \multirow[t]{2}{*}{9} & 1 & 2.950 & 2.950 & 0.000 & 2.950 & 0.090 & 0.090 & 0.000 & 0.090 & 10.746 & 10.746 & 0.000 & 10.746 \\
\hline & & \multicolumn{4}{|c|}{$\mathrm{CVg}$} & \multicolumn{4}{|c|}{ VR } & \multicolumn{4}{|c|}{ LSD } \\
\hline 2 & 36 & 15.052 & 24.687 & 9.634 & 20.338 & 4.507 & 10.465 & 5.958 & 7.582 & 2.405 & 4.493 & 2.088 & 3.612 \\
\hline 3 & 84 & 17.229 & 23.963 & 6.734 & 20.397 & 4.473 & 7.744 & 3.271 & 6.207 & 2.056 & 3.208 & 1.151 & 2.721 \\
\hline 4 & 126 & 18.212 & 22.912 & 4.701 & 20.422 & 4.238 & 6.382 & 2.144 & 5.376 & 1.821 & 2.628 & 0.806 & 2.292 \\
\hline 5 & 126 & 18.834 & 22.363 & 3.528 & 20.436 & 4.158 & 5.505 & 1.347 & 4.808 & 1.773 & 2.227 & 0.454 & 2.022 \\
\hline 6 & 84 & 19.282 & 22.010 & 2.728 & 20.445 & 3.949 & 4.874 & 0.925 & 4.389 & 1.697 & 1.954 & 0.258 & 1.830 \\
\hline 7 & 36 & 19.595 & 21.524 & 1.929 & 20.451 & 3.779 & 4.393 & 0.614 & 4.062 & 1.604 & 1.764 & 0.160 & 1.685 \\
\hline 8 & 9 & 19.945 & 21.120 & 1.175 & 20.455 & 3.644 & 3.943 & 0.299 & 3.800 & 1.533 & 1.611 & 0.078 & 1.569 \\
\hline \multirow[t]{2}{*}{9} & 1 & 20.459 & 20.459 & 0.000 & 20.459 & 3.582 & 3.582 & 0.000 & 3.582 & 1.475 & 1.475 & 0.000 & 1.475 \\
\hline & & \multicolumn{4}{|c|}{ LSD $\%$} & \multicolumn{4}{|c|}{ SA } & \multicolumn{4}{|c|}{ FI } \\
\hline 2 & 36 & 25.753 & 59.794 & 34.042 & 43.322 & 0.849 & 0.978 & 0.129 & 0.933 & 2.857 & 42.857 & 40.000 & 17.884 \\
\hline 3 & 84 & 23.446 & 40.591 & 17.146 & 32.537 & 0.918 & 0.979 & 0.062 & 0.955 & 16.190 & 48.571 & 32.381 & 29.546 \\
\hline 4 & 126 & 21.574 & 32.490 & 10.916 & 27.369 & 0.949 & 0.982 & 0.033 & 0.966 & 26.667 & 53.333 & 26.667 & 36.878 \\
\hline 5 & 126 & 20.855 & 27.611 & 6.756 & 24.118 & 0.964 & 0.983 & 0.019 & 0.973 & 30.476 & 56.190 & 25.714 & 42.668 \\
\hline 6 & 84 & 19.633 & 24.233 & 4.600 & 21.818 & 0.972 & 0.984 & 0.012 & 0.978 & 34.286 & 58.095 & 23.810 & 48.311 \\
\hline 7 & 36 & 18.674 & 21.711 & 3.037 & 20.077 & 0.978 & 0.985 & 0.007 & 0.981 & 46.667 & 60.000 & 13.333 & 54.153 \\
\hline 8 & 9 & 17.930 & 19.404 & 1.473 & 18.698 & 0.982 & 0.985 & 0.003 & 0.983 & 53.333 & 63.810 & 10.476 & 59.259 \\
\hline 9 & 1 & 17.570 & 17.570 & 0.000 & 17.570 & 0.985 & 0.985 & 0.000 & 0.985 & 61.905 & 61.905 & 0.000 & 61.905 \\
\hline
\end{tabular}



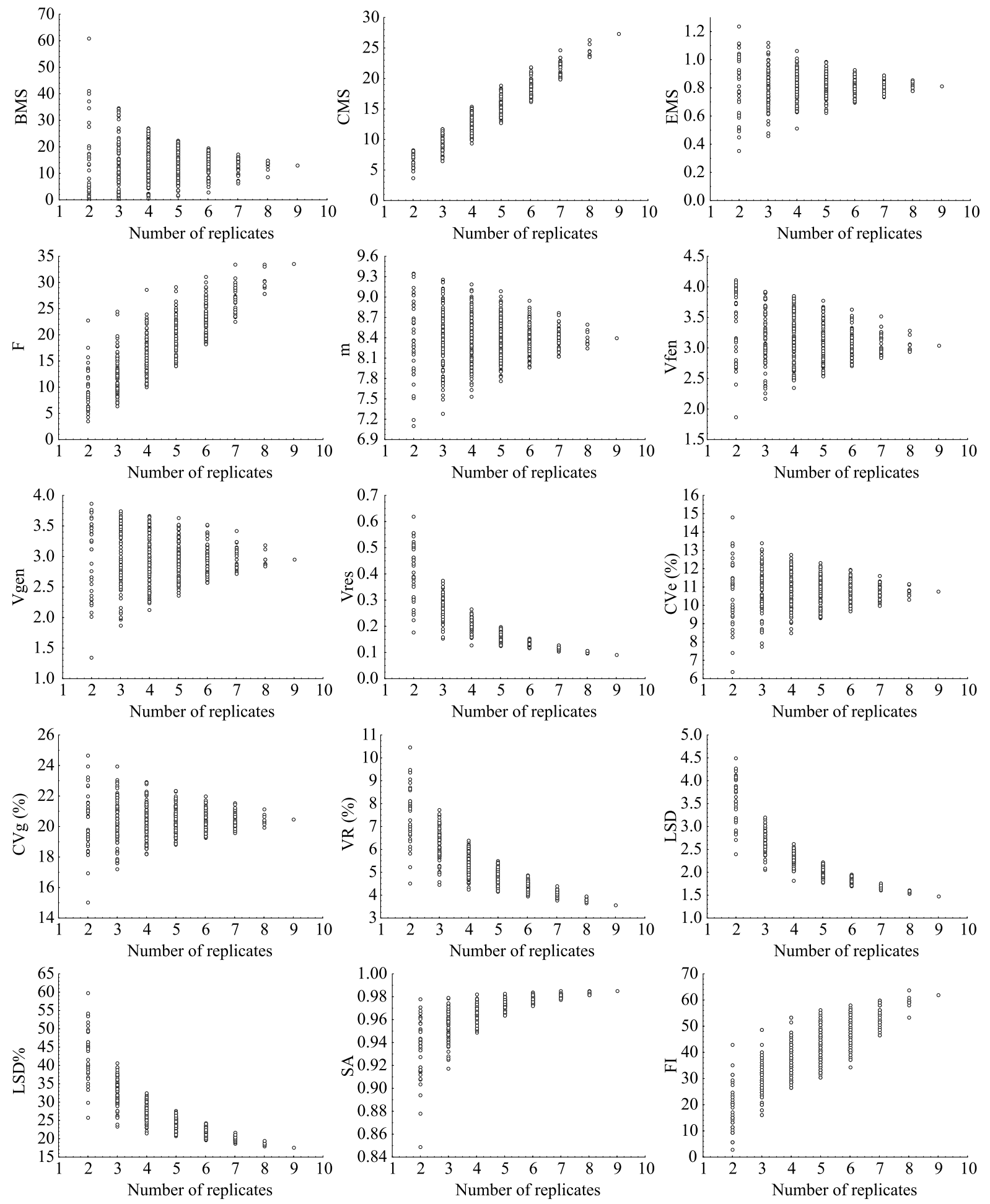

Figure 1. Estimates of block mean square (BMS), cultivar mean square (CMS), error mean square (EMS), cultivar F-test value (F), overall experimental mean (m), mean phenotypic variance (Vfen), mean genotypic variance (Vgen), mean residual variance (Vres), coefficient of experimental variation (CVe), coefficient of genetic variation $(\mathrm{CVg})$, variation rate (VR), least significant difference (LSD), LSD as a percentage of the mean for the experiment (LSD\%), selection accuracy (SA), and Fasoulas' differentiation index (FI) for grain yield $\left(\mathrm{Mg} \mathrm{ha}^{-1}\right)$ of 15 corn (Zea mays) cultivars, obtained in experiments using combinations of $2,3, \ldots, 9$ replicates. 
becomes Vfen $=0.8139 / \mathrm{r}+2.9500 ; \mathrm{R}^{2}=0.0444$. However, based on the mean of the experiments for each $\mathrm{r}\left(\right.$ Vfen $\left.=0.8139 / \mathrm{r}+2.9500 ; \mathrm{R}^{2}=1\right)$, the relationship was perfect, since Vgen (2.950) and EMS (0.8139) remain constant as $r$ increases. Note that Vgen remained constant at 2.950 regardless of $r$, which is expected considering the number of cultivars $(n=15)$ used was the same for all experiments.

The minimum and maximum values, amplitudes, and averages for Vres decreased as $r$ was increased. The decrease in amplitude indicates improved estimate precision, whereas the decrease in the mean suggests an improvement in experimental precision. The relationship between Vres and $\mathrm{r}$, based on the 502 experiments, was Vres $=0.8139 / \mathrm{r} ; \mathrm{R}^{2}=$ 0.8074 . However, based on the means of individual experiments for each $\mathrm{r}\left(\right.$ Vres $\left.=0.8139 / \mathrm{r} ; \mathrm{R}^{2}=1\right)$, the relationship was perfect, since EMS (0.8139) remains constant as $r$ increases.

The means (in percentage) of $\mathrm{CVe}$ and $\mathrm{CVg}$ remained similar as $r$ increased. This is explained by the constant mean values of EMS, $m$, and Vgen as $r$ increased. The fact that minimum values increased and maximum values and amplitude decreased shows improved precision in the estimates for CVe and CVg. Based on the average for EMS (0.8139), $\mathrm{m}$ (8.395), and Vgen (2.950), for each $\mathrm{r}$, the ratio of $\mathrm{CVg}$ to $\mathrm{CVe}$ remained constant at 1.9039 regardless of $r$, indicating that genetic variability was higher than environmental variability.

VR can be expressed as VR $=\mathrm{CVe} \times \mathrm{r}^{0.5}$, which represents the decreasing values in the power model. Therefore, the relationship between VR and $r$, based on the 502 experiments, was VR $=10.7209 \times \mathrm{r}^{0.4982}$; $\mathrm{R}^{2}=0.7695$, whereas, based on the average of the experiments for each $\mathrm{r}$, it was VR $=10.7194 \times \mathrm{r}^{0.4984}$; $\mathrm{R}^{2}=0.9999$. Considering EMS (0.8139) and the mean (8.395) remained constant as $\mathrm{r}$ increased, the relationship is perfect $\left(\mathrm{R}^{2}=1\right)$ and expressed by VR $=10.7459 \times \mathrm{r}^{0.5}$. In terms of $\mathrm{r}$, this statistic is better than $\mathrm{CVe}$ for evaluating experimental precision, as highlighted by Pimentel Gomes (1991), Storck et al. (2016), and Cargnelutti Filho et al. (2014). Since CVe remains constant regardless of $r$, based on the $\mathrm{CVe}$ of an experiment, $\mathrm{r}$ can be redefined to the desired VR values using the expression $r=(\mathrm{CVe} / \mathrm{VR})^{2}$.

LSD \% decreased in terms of the minimum, maximum, amplitude, and average values, in line with the power model. As $r$ is increased, the estimation of
LSD and LSD\% improves, and the estimated values decrease, so that smaller differences between cultivar means are identified as significant. This is evidence of improved experimental precision and shows that LSD and LSD \% are better than VR and CVe for this purpose, as discussed in Cargnelutti Filho et al. (2014). This power model pattern shows that the greatest enhancements in precision are produced by few replicates and also that, beyond a certain number of replicates, precision tends to stabilize and gains in precision gradually decrease.

The relationship between LSD and $r$, based on the means of the experiments for each $\mathrm{r}$, showed decreasing power model values ( $\mathrm{LSD}=5.2737 \mathrm{r}^{-0.587} ; \mathrm{R}^{2}=0.9968$ ). The relationship between $\mathrm{LSD} \%$ and $r$, based on the means of experiments for each $r$, also showed decreasing power model values $(\mathrm{LSD} \%=63.403$ $\left.\mathrm{r}^{0.592} ; \mathrm{R}^{2}=0.9967\right)$. For the specific situation of 15 corn cultivars, these equations can be used to redefine $r$ to obtain the desired LSD and LSD\%. For instance, with the aim of obtaining very low LSD\% values (LSD\% $\leq 9.0$ ), guaranteeing very high experimental precision, according to the precision classes established by Lúcio et al. (1999) for corn, the $\mathrm{r}$ obtained by $9.0=63.403 \mathrm{r}^{-0.592}$ would be $r \approx 27$ replicates. This result is in alignment with those of Nesi et al. (2010), who found that it is not possible to perform high precision trials solely by increasing the number of replicates.

SA showed increases in the minimum, maximum, and mean values, as well as a decrease in amplitude, with a tendency for stabilization. According to the class boundaries established by Resende \& Duarte (2007), SA was high $(0.70 \leq \mathrm{SA}<0.90)$ only in three experiments with 2 replicates; in the other experiments with two replicates and all experiments with 3, 4, $5,6,7,8$ and 9 replicates, experimental precision was very high $(\mathrm{SA} \geq 0.90)$. Therefore, it could be inferred that 2 replicates are sufficient to confer very high experimental precision in this experiment. However, as $\mathrm{r}$ increased, there was a decrease in $\mathrm{VR}, \mathrm{LSD}$, and $\mathrm{LSD} \%$ and an increase in $\mathrm{F}$ and $\mathrm{SA}$, suggesting improved experimental precision, even for experiments whose $\mathrm{F}$ and SA values indicate very high experimental precision (Resende \& Duarte, 2007).

Since F is directly related to SA and both are statistics of experimental precision (Resende \& Duarte, 2007), Vgen and EMS, obtained in the analysis of variance of an experiment, can be used to redefine $r$ for future 
experiments in order to obtain desired values of $\mathrm{F}$ and $\mathrm{SA}$. To do this, isolating $\mathrm{r}$ in the expression $\mathrm{F}=1+$ $(r V g e n / E M S)$ gives $r=(F-1)$ EMS/Vgen. Similarly, replacing $F$ in the $S A$ expression $\left[S A=(1-1 / F)^{0.5}\right.$ ] with $\mathrm{F}=1+(\mathrm{rVgen} / \mathrm{EMS})$ and isolating $\mathrm{r}$, gives $\mathrm{r}=$ $\left(\right.$ EMS $\left.\times \mathrm{SA}^{2}\right) /\left(\operatorname{Vgen}\left(1-\mathrm{SA}^{2}\right)\right)$.

Since the researcher's main aim is to discriminate cultivars, a statistic measuring the percentage of significant differences detected is essential. Experiments with high experimental precision would, therefore, better discriminate cultivars. Based on this approach, FI, which measures the percentage of significant contrasts from 0 to $100 \%$, would be an appropriate statistic for determining experimental precision; this allows studying classes of experimental precision, as already suggested by Cargnelutti Filho \& Storck (2007).

Minimum, maximum, and average values of FI increased and amplitude decreased as $r$ increased, indicating improved FI estimation and better cultivar discrimination as $r$ increased. The mean FI for the 36 experiments with 2 replicates was $17.884 \%$, whereas for those with 9 replicates it was $61.9048 \%$ (Table 2), i.e., of the 105 contrasting means for the combinations of the 15 cultivars in groups of $2\left(\mathrm{C}_{(15.2)}=105\right), 65$ were significant based on Tukey's test. These results confirm the hypothesis that, even for experiments classified as of very high experimental precision based on $\mathrm{F}$ and $\mathrm{SA}$, experimental precision (higher FI) improved as $\mathrm{r}$ was increased.

Table 2. Average grain yield of 15 corn (Zea mays) cultivars with 9 replicates ${ }^{(1)}$.

\begin{tabular}{lc}
\hline Cultivar & Grain yield $\left(\mathrm{Mg} \mathrm{ha}^{-1}\right)$ \\
\hline AG 9045 & $11.959 \mathrm{a}(13)$ \\
P30F53H & $11.034 \mathrm{ab}(11)$ \\
BG7060HR & $10.015 \mathrm{bc}(9)$ \\
BG7046 & $9.691 \mathrm{bc}(9)$ \\
BG7049H & $9.309 \mathrm{~cd}(5)$ \\
BG7051H & $8.581 \mathrm{cde}(3)$ \\
P1630H & $8.114 \mathrm{de}(3)$ \\
20A55Hx & $8.043 \mathrm{de}(3)$ \\
2B688HX & $7.884 \mathrm{de}(3)$ \\
1H768 & $7.845 \mathrm{de}(3)$ \\
AG5011 & $7.698 \mathrm{e}(3)$ \\
LG 6304YG & $7.371 \mathrm{ef}(0)$ \\
KSP 04 & $6.197 \mathrm{f}(0)$ \\
P2530 & $6.165 \mathrm{f}(0)$ \\
KSP 3248 & $6.024 \mathrm{f}(0)$ \\
\hline
\end{tabular}

(1)Means followed by the same letter do not differ by Tukey's test, at $5 \%$ probability. The numbers in parentheses indicate the number of means in which the $i^{\text {th }}$ cultivar was statistically greater after Tukey's test.
The values of F, VR, LSD, LSD \%, SA, and FI tend to stabilize when a certain $r$ is reached; therefore, the gains achieved in discriminating cultivars decrease from this point on. Visual examination showed statistical stabilization in approximately 6 replicates, which is the number recommended by Resende \& Duarte (2007). This means that even experiments with only 2 replicates, classified as of very high experimental precision according to the boundaries of F and SA (Resende \& Duarte, 2007), could benefit from improved precision by an increase in $\mathrm{r}$.

The obtained results show that it is important to study the experimental class boundaries of $F$ and SA, confirming the findings of Cargnelutti Filho \& Storck (2007) regarding the need to investigate FI class boundaries to improve precision using this statistic. However, establishing experimental precision classes was not the main aim of the present study. Six replicates can be taken as the benchmark, but more studies combining number of cultivars and number of replicates in corn and other crops are still necessary. It should be noted that a low number of replicates can lead to greater inferential uncertainty, but that a high number of replicates might not be compatible with the experimental protocol.

\section{Conclusions}

1. Increasing the number of replicates improves the estimates of experimental precision statistics, as well as experimental precision, although, after a certain number of replicates, gains in precision gradually decrease.

2. Increasing the number of replicates is important for improving corn (Zea mays) cultivar discrimination.

3. Six replicates can be used as a benchmark for experiments with corn cultivars.

4. Fasoulas' differentiation index is an appropriate statistic for assessing experimental precision, since it takes into account the percentage of significant contrasts.

\section{Acknowledgments}

To Conselho Nacional de Desenvolvimento Científico e Tecnológico (CNPq, process number 305057/2013-8) and to Coordenação de Aperfeiçoamento de Pessoal de Nível Superior (Capes), for scholarships; and to fellow students and volunteers, for assistance in data collection. 


\section{References}

BANZATTO, D.A.; KRONKA, S. do N. Experimentação agrícola. 4.ed. Jaboticabal: FUNEP, 2013. 237p.

CARGNELUTTI FILHO, A.; STORCK, L. Estatísticas de avaliação da precisão experimental em ensaios de cultivares de milho. Pesquisa Agropecuária Brasileira, v.42, p.17-24, 2007. DOI: $10.1590 /$ S0100-204X2007000100003.

CARGNELUTTI FILHO, A.; STORCK, L. Medidas do grau de precisão experimental em ensaios de competição de cultivares de milho. Pesquisa Agropecuária Brasileira, v.44, p.111-117, 2009. DOI: 10.1590/S0100-204X2009000200001.

CARGNELUTTI FILHO, A.; STORCK, L.; GUADAGNIN, J.P. Número de repetições para a comparação de cultivares de milho. Ciência Rural, v.40, p.1023-1030, 2010. DOI: 10.1590/S010384782010005000073.

CARGNELUTTI FILHO, A.; STORCK, L.; TOEBE, M.; BURIN, C.; ALVES, B.M.; FACCO, G.; NEU, I.M.M. Precisão experimental relacionada a tamanhos de parcelas, números de tratamentos e repetições em nabo forrageiro. Pesquisa Agropecuária Brasileira, v.49, p.428-439, 2014. DOI: 10.1590/ S0100-204X2013000700007.

CRUZ, C.D. GENES: a software package for analysis in experimental statistics and quantitative genetics. Acta Scientiarum. Agronomy, v.35, p.271-276, 2013. DOI: 10.4025/ actasciagron.v35i3.21251.

CRUZ, C.D.; REGAZZI, A.J.; CARNEIRO, P.C.S. Modelos biométricos aplicados ao melhoramento genético. 4.ed. Viçosa: UFV, 2012. v.1, 514p.

CURTI, G.L.; NESI, C.N.; VOLF, A. Avaliação do período crítico de interferência e do número de repetições em experimentos sobre plantas daninhas na cultura do milho. Unoesc \& Ciência ACET, v.5, p.137-144, 2014.
FASOULAS, A.C. Rating cultivars and trials in applied plant breeding. Euphytica, v.32, p.939-943, 1983. DOI: 10.1007/ BF00042176.

GORDÓN-MENDOZA， R.; CAMARGO-BUITRAGO, I. Selección de estadísticos para la estimación de la precisión experimental en ensayos de maíz. Agronomía Mesoamericana, v.26, p.55-63, 2015. DOI: 10.15517/am.v26i1.16920.

LÚCIO, A.D.; STORCK, L.; BANZATTO, D.A. Classificação dos experimentos de competição de cultivares quanto a sua precisão. Pesquisa Agropecuária Gaúcha, v.5, p.99-103, 1999.

NESI, C.N.; DAL BÓ, H.C.; GUIDONI, A.L.; BRINGHENTI, C. Número mínimo de repetições em experimentos de competição de híbridos de milho. Revista de Ciências Agroveterinárias, v.9, p.74-81, 2010.

PIMENTEL-GOMES, F. O índice de variação, um substituto vantajoso do coeficiente de variação. Piracicaba: IPEF, 1991. 5p. (IPEF. Circular técnica, 178).

PIMENTEL-GOMES, F. Curso de estatística experimental. 13.ed. Piracicaba: Nobel, 1990. 468p.

RAMALHO, M.A.P.; FERREIRA, D.F.; OLIVEIRA, A.C.de. Experimentação em genética e melhoramento de plantas. 3.ed. Lavras: UFLA, 2012. 305p.

RESENDE, M.D.V. de; DUARTE, J.B. Precisão e controle de qualidade em experimentos de avaliação de cultivares. Pesquisa Agropecuária Tropical, v.37, p.182-194, 2007.

STORCK, L.; GARCIA, D.C.; LOPES, S.J.; ESTEFANEL, V. Experimentação vegetal. 3.ed. Santa Maria: UFSM, 2016. 200p.

VELINI, E.D.; PALMA, V.; SOUZA, L.S.; MARTINS, D. Interferência de plantas daninhas na cultura do milho. I - Efeito do número de repetições sobre a precisão dos resultados obtidos. Planta Daninha, v.24, p.435-442, 2006. DOI: 10.1590/S010083582006000300003.

Received on september 11, 2017 and accepted on February 22, 2018

Pesq. agropec. bras., Brasília, v.53, n.11, p.1213-1221, Nov. 2018 DOI: 10.1590/S0100-204X2018001100003 